$1-1-1889$

\title{
Six months experience in running a creamery; Improved process of handling cream and churning
}

John A. Myers

Follow this and additional works at: https://researchrepository.wvu.edu/ wv_agricultural_and_forestry_experiment_station_bulletins

\section{Digital Commons Citation}

Myers, John A., "Six months experience in running a creamery ; Improved process of handling cream and churning" (1889). West Virginia Agricultural and Forestry Experiment Station Bulletins. 6.

https://researchrepository.wvu.edu/wv_agricultural_and_forestry_experiment_station_bulletins/6 @ WVU. It has been accepted for inclusion in West Virginia Agricultural and Forestry Experiment Station Bulletins by an authorized administrator of The Research Repository @ WVU. For more information, please contact ian.harmon@mail.wvu.edu. 
West Virginia University Libraries

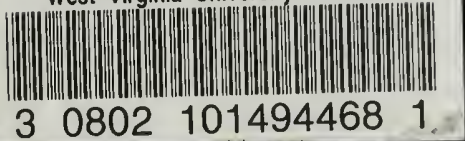





\section{STILETIN NO. 6}

or THE

\section{WEST VIRGINIA}

\section{Agricultural Experiment Station}

AT

\section{MORGANTOWN, W, VA,}

SiX MONTHS EXPERIENCE IN RUNNING A CREAMERY. IMPROVED Process of HANDLing CREAM AND CHuRning.

John A. Myers, Director.

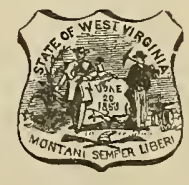

CHARLESTON :

Moses W. Donnally, Public Printer. 1889 . 
BOARD OF REGENTS OF THE WEST VIRGINIA UNIVERSITY.

District.

Name of liegent.

P. O. Address.

1. HON. J. B. SOMMERVILLE,

Wheeling.

2. " CLARENCE L. SMITH,

Fairm nt.

3. " PEREGRIN HAYS,

Glenville,

4. " D. D. JOHNSON,

Longreach.

5. " JOIIN 'D. SCHILLING,

Spencer.

6. " EDIVARD A. BENNETT,

Euntington.

7. "WIRT A. FRENCH,

Princeton.

S. " M. J. KESTER,

Union.

9. " D. O. GALLAIIER,

Charleston.

10. " IHOS. J. FARNSWOITH, Buckhannon.

11. "JOSEPH MORELAND, Morgantown.

12. "JOHN A. ROBINSON, Patterson's Depot.

13. DR. W. W. BLOWN, Kabletown.

MEMBERS OF TUE STALION COMMITTEL.

Hon. JOHN A. ROBINSON, Hon. PEREGRIN IIAY,

" JOSEPH MORELAND, " THOS J.FARNSTOR'T'I, Dr. JOHN A. MYERS, D:. W. W. BROWN.

President of the University.

E. M. TURNER.
Treasurer.

JOIN I. HARVEY.

STATION STAFE.

JOHN A. MYERS, PI. D.,

Direct $x$.

A. C. MAGRUDER, B. S.,

Creamery-man.

II. R. BALDWIN, J. R.,

Chemist

S. T. MAYERS,

Stenographer. 
MILK.

Milk must be relied upon by the dairy farmer as his chief source of profit, to be sold either as fresh milk, as cream, as butter or cheese. The great mass of farmers are so located that it will not ba profitable for them to attempt to sell the milk or cream as such, and in order to make the products of the cow marketable, they must be converted into either butter or cheese.

The milk supply of creameries varies in composition through a relatively wide percentage; dependent partly upon causes clearly understood, such as breeds of stock. age of animals, period of lactation, character of food, etc., and partly upon conditions with which we are yet unfamiliar, such as nervous condition of the animals, constitutional peculiarties, conditions of health, etc.

The average composition of unadulterated milk is given as :

VARIATIONS.

A verage. Minimum. Maximum.

- Water, 87.5 per ct. 85 . per ct. 90 . per ct.

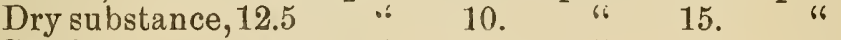

\begin{tabular}{|c|c|c|c|c|c|c|c|}
\hline & & & & & & & \\
\hline & Casein, & 3.2 & 66 & 2. & 6 & 4.5 & 6 \\
\hline & Albumen, & 0.6 & .6 & 0.2 & 66 & 0.8 & 6 \\
\hline Iatter. & (Lactoprotein,* & 0.1 & $:$ & 0.08 & 6 & 0.35 & 66 \\
\hline & Milk sugar, & 4.5 & $\therefore$ & 3. & 66 & 6. & .6 \\
\hline & Butter fat, & 3.4 & "6 & 3. & "6 & & 6 \\
\hline & Specific gravity & 1.031 & "6 & 1.029 & 6 & 1.033 & 6 \\
\hline & & n. & $" 6$ & 0.6 & 66 & 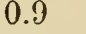 & 6: \\
\hline
\end{tabular}

The milk delivered at our station creamery gave the following tes.ts for butter fat for the first six month:

May, $\quad 3.95$ per cent. fat.

June, $\quad 4.21$ per cent. fat.

July, $\quad 4.06$ per cent. fat.

August, 4.18 per cent. fat.

September, 4.26 per cent. fat.

October, 4.28 per cent. fat.

BUTTER.

For the present we discuss only the production of butter, and by butter we mean the mechanical mixture of fats produced by causing the fat of milk to coalesce into masses of sufficient size to be readily ccllected and separated from the milk. This is accomplished by submitting the milk at the proper temperature to violent agitation. Approximately butter consists of 80 to 90 per cent. of butter fat, 2 to 7 per cent. of salts, 1-2 to 3 per cent. of curd, 8 to 15 per cent. of water.

*Doubtful. 
WATER IN BUTERR.

It is an easy matter for butter to have such a large quantity of water intermixed with it, that it may amount to an adulteration. It is claimed that as much as 60 per cent. of water can be introduced into butter and the whole sold as butter. It is not an uncommon thing for the country butter to come into the markets in the summer time with as much as 30 per cent. of water mixed with it. This mixing of water with butter, or the imperfect extraction of water from butter, has an important bearing upon the subject of determining the butter producing capacity of cows, and also of judging the quality of butter upon the market.

At our Station Creamery after the butter is in the granulated state, it is our habit to allow it to drain until all of the wash water that will do so, drains out. This usually requires about fifteen minutes. It is then placed upon the butter worker, and fine dairy salt added in the proportion of $1 \frac{1}{4}$ ounces to a pound of butter. The butter is then worked rapidly, and from 10 to 20 per cent. of the original weight of the butter is worked off as salt water. Our Creamery butter, when placed upon the market contains from about 8 to 12 per cent of water.

\section{LOSS IN HANDLING BUTTER.}

The nature of butter precludes the handling of it without some loss. This occurs in transferring from one vessel to another, in working and printing the butter and in failing to secure all of the butter from the milk or cream churned. The latter has been, up to the present time, one of the principal sources of loss, and few have taken time to estimate the extent of it.

Prof. C. A. Wulff of the Indiana Station has figured this out, and we incorporate, herewith, a quotation from him upon this subject. (See Dairy World Vol. 8, No. 6, Page 233.) viz :

"The fat in milk depends principally upon three particulars,

The time after the dropping of the calf, the food and breed, but in all controlling fat, we must consider how great a result is to be credited to the influence of very small differences.

For instance, we will give the prices of the fat in the milk, quoting $1 \mathrm{lb}$. butter equal to $30 \mathrm{cts}$. 
LOSS OF BUTTER FAT, PER 100 LBS. MILK.

Per cent. of fat left in the milk.

0.05

0.10

0.15

0.20

0.24

0.25

0.30

0.35

0.40

0.45

0.50

0.55

0.60

0.65

0.70

0.75

0.80

0.85

0.90

0.95

1.00
Lbs, butter.

0.06

0.12

0.18

0.24

0.36

0.30

0.36

0.42

0.48

0.54

0.60

0.66

0.72

0.78

0.84

0.90

0.96

1.02

1.08

1.14

1.20
Cents.

1.8

3.6

5.4

7.2

10.5

9.0

10.8

12.6

14.4

16.2

180

19.8

2 L. 6

23.4

252

27.0

28.8

306

32.4

34.02

36.0

Before using these figures, we must remember that in the skimmi.k is always left some fat, differing in amount, according to differing methods of skimming. By use of separators not more than 0.16 per cent. of fat is left in the skim-milk. The buttermilk contains about 0.06 per cent. of fat, making 0.22 per cent. of fat in the milk that is not to become butter.* If, therefore, of your cows yielding an average $6,000 \mathrm{lbs}$. of milk a year there is one that gives, for instance, 257 per cent, and another giving 3.82 per cent. of fat on the average, the former pays for her food and care as follows: 2.57-0.22 equals 2.35 per cent. fat gives $2.82 \mathrm{lbs}$. (2.35 lbs.?) butter per $100 \mathrm{lbs}$. milk, and per year $169.2 \mathrm{lbs}$. (141. lbs. ?) butter equals $\$ 50.76(\$+2.30)$. The latter gives milk with $382-022$ equal 3.60 per cent. of fat becoming butter or $4.32 \mathrm{lbs}$. (3.69?) lbs. butter out of 100 lbs. milk and per year $259.2 \mathrm{lbs}$. butter (216 lbs?) equal to $\$ 77.76(\$ 64.80$ ?)."

* Mr. Wulff has made a mistake in his calculations, unless they be based upon other figures than those given in the article quoted. It is possible that he has passed from the percentage of butterfat to product of marketable butter. As I understand it, 2.35 per cent. of fat is theoretically equal to $2.35 \mathrm{lbs}$. of butter per $100 \mathrm{lbs}$ of milk, instead of $2.82 \mathrm{lbs}$. of butter as given by him. The second cow would, according to this, make 3.60 lbs of butter instead of 4.32 lbs, as stated by him. I, therefore, quote his language, but substitute the figures which agree with the chemical analysis of the milk. 
The difference between the revenue of these two cows, a year is $\$ 22.50$. The average difference in fat of their milk equals 1.25 per cent. For a herd of ten cows, it makes $\$ 225$ a year, and for 100 cows the yearly loss is $\$ 2,250$, if the average yield of fat in the herd is 2.57 , when it could be 3.82 per cent-a sufficient reason, we think, for the proprietor and breeder to know not only his herd, but also each individual, as to its fat producing ability.

It will be seen by the above that he calculates that a separator may lose as much as 0.16 per cent. of the fat in the skim-milk, and that buttermilk will contain about six-hundredths per cent. of fat, making a total loss of 0.22 per cent of fat due to inability to properly extract it from the milk.

The average loss of butter fat in skim-milk at this station during the months of July and August was 0.19 each, and in the buttermilk for July it was 0.57 per cent., and for August 0.47 per cent. We were churning ripened cream. It should be remembered that this, however, is not 0.76 and 0.66 respectively of the whole milk. The 0.19 per cent. is of the whole milk, while the 0.57 and the 0.47 per cent. are percentages of the cream separat. ed, or percentages of 1.5 of the whole milk. For example, supposing we are handling 1000 lbs. of milk. There would be about 800 lbs. of skim-milk containing 0.19 per cent. of fat equal to 1.52 lbs. of butter, while the 200 lbs. approximately, of buttermilk. would contain in July 0.57 per cent. of fat, or 1.14 pounds of but: ter, and for August 0.47 per cent. of fat, or 0.94 lbs. of butter. This makes a total loss of butter fat per $1000 \mathrm{lbs}$. of milk for July of $2.66 \mathrm{lbs}$, and for August $2.46 \mathrm{lbs}$., equivalent to $0.26 \mathrm{per}$ cent. and 0.24 per cent. of the whole milk. This may appear unnecessarily large at first thought, but when we remember that this number is multiplied by five, or more where the milk is handled as it ordinarily is at the farm houses, we may consider it a material advance. It is confessedly much too large, but was about as well as could be done until some improvement in handling or churning milk was made.

In order to save this wastage, and also to secure butter of better keeping qualities, we endeavored to churn sweel cream. We also have a demand for sweet cream butter, which necessitates our churning it regularly. This, however, entailed a loss of about ten per cent., and frequently as high as fifteen per cent. of the cream which passed off in the buttermilk unchurned, unless the churning was carried so far as to damage the quality of the butter. The churning of sweet cream in the past has always met with this objection.

\section{NEW PROCESS OF HANDLING CREAM.}

The cream, as it comes from the separator, is a mixture of irregular composition, and in churning some portions of it usually unite and granulate before other portions of it are ready to pass into butter, so that the result has been that either too small a 
yield has been secured, or the quality of the butter has been spoiled to increase the yield. A number of efforts were made by us to overcome the difficulty by attempting to regulate the temperature, revolutions of the churn, by drawing off the milk after the granulation first took place, and churning the remainder separately, etc., until at last our creamery-man struck upon the idea of running the sweet buttermilk throngh the separator. This takes out all the unchurned cream and leaves a skimmed buttermi k containing less than 1-I0, generally scarcely a trace of butter fat in the skimmed buttermilk.

Our separator is now run by our creamery-man, Mr. A. C, Magruder, so that it is the rarest thing that an appreciable amount of fat is left in the skim milk. Iu fact, by our process here we now usually fail to detect more than a trace of fat present in the skim-milk.

\section{METHODS OF ANALYSIS.}

We have used as methods of testing Short's method, the lactobutyrometer and lactocrite. Some may be skeptical as to the results secured by the first two. We bolieve, however, that all will admit that the lactocrite works as closely as the most careful chemist can work by the gravometric method.

\section{VARIATION OF TESTS.}

During the month of July, we carried through our tests of milk by the lactociite, Short's method and by the lactobutyrometer.

The averages for the month were as follows:

Lactocrite 4.08 per cent.

Short's method 4.05 per cent.

Lactobutyrometer 4.06 per cent.

This is the average of about 150 analyses of the same samples of milk.

During the month of August these stood as follows:

Lactocrite 4.25 per cent.

Short's method 3.98 per cent.

Lactobutyrometer 4.32 per cent.

This month Short's mothod is out of line owing to the quality of tubes supplied by Cornish, Curtis \& Greene. It is only a delusion to apply any test with imperfect or improperly graduated apparatus.

As before stated, by running the separator with more care, it was found that we could skim the milk to within 1-10 of 1 per cent. as is shown by the following record: 
Oct. 30, Skim-milk blank.

\begin{tabular}{|c|c|c|}
\hline ov. & 5 & " \\
\hline & 8 & $" 6$ \\
\hline " & $\begin{array}{c}9 \\
16\end{array}$ & " \\
\hline " & 18 & 16 \\
\hline “6 & 19. & “ \\
\hline " & 20 & $"$ \\
\hline "6 & $\begin{array}{l}21, \\
22\end{array}$ & " \\
\hline
\end{tabular}

The sweet cream buttermilk before separation contained .

Per cent. of fat.

October $30,1.543$

" $31,7.514$

November $4,1.441$

" $9,1.543$

" $14,2.563$

" $\quad 19,1.747$

.6 $\quad 20,2.461$

. $\quad 21,1.543$

" $22,1.951$

After separation, it contained less than 0.1 per cent. or is blank as follows:

Per cent of fat.

October 30, Blank

" 31 "

November, 4, "

$\begin{array}{lrl}\text { " } & 9, & \text { " } \\ \text { " } & 14, & \text { " } \\ \text { " } & 19, & \text { " } \\ \text { " } & 21, & \text { " } \\ & 22, & \text { " }\end{array}$

The above constitutes a series of tests made after our arrangements for controlling the temperature and flow of milk into the separator had been perfected.

NEW METHOD OF CHURNING SWEET CREAM.

By this process, it will be seen that the milk is skimmed by the separator until the butter fat is extracted almost to within the limits of chemical analysis. The quality of the butter is main tained and it is all handled in the granulated condition just as if it had been churned in the usual way.

The milk at the Creamery is delivered sweet every_morning, 
and embraces the evening and morning milkings. When the weather is sufficiently warm to cause the milk to sour, the milkings are brought to the Creamery in separate vessels. The milk as delivered by the farmers is immediately run through the separator, and about one-fifth thrown out as cream. The other fourfifths is taken home by the farmers as skim-milk. As soon as we are done separating, the cream is cooled to from fifty to fifty five degrees to remove the animal heat and reduce it to the proper temperature for churning. It is then put into a Blanchard revolving churn and churned at from thirty eight to forty revolutions to the minute until the butter granulates in the usual manner; when the churn is stopped, the butter milk drawn off and again run through the separator, as mentioned before.

\section{EXACTNESS OF THE WORK.}

We do not claim that we scecure as butter every parlicle of fat in the milk. Our tests, however, indicate to us that we are working by this process to within the limits of error in chemical anal$y$ ses and closer than it is possible for us to work by the ordinary system of churning. It remains to be tried in other Creameries and tested in other laboratories as to whether the process is worthy of general acceptation. With us it has worked well.

\section{DIFFICULTIES IN BUILDING UP A SELECT TRADE.}

Great difficulty was experienced in finding a market for our product at the time of starting. On starting, shipment after shipment of butter to commission merchants in the East and to other large cities was sold to them at reduced rates, and our butter condemned by them as may be seen by the following letters. We were then churning ripened cream.

DEAR SIR :

Philadelphia, May, 18, 1889.

I shall be glad to handle the product of your creamery, but can only do it to your advantage and satisfaction and mine when you make a uniformly good article and send regularly. You may not know that it takes a little time to get a good trade on butter, or rather on a particular mark of butter. At this present time, which condition will continue, no doubt, until perhaps July, the state of the butter market is quite unsatisfactory both as to price, which is low, and to movement which is slow, and one can not get the top price for an article, however good, that is received only occasionally.

My commission cn solid packed butter is 5 per cent. On pound or half pound prints it is 2 cts. per pound.

I shall be pleased to hear from you by letter and shipment and will do the best I can for you.

Respectfully yours,

"O. W. W", 
DEAR SIR :

Philadelphia, June 13 th, 1889.

Your butter is sweet, but appears to lack flavor and does not wive our customers satisfaction. Of course, our customers will be judges of what will suit them.

Yours truly,

"J."

DEAR SIR :

Philadelphia, June 4th, 1889.

The tub of butter was received from you on the 23rd of May. We placed it in our refrigerator when it came in and we have had such an overstocked and unsatisfactory market since that we have never taken it out or offered it. Your butter is not strictly fine. and will not compare with our fine makes. Fancy Elgin Creamery is selling at, 17 and 18 cents, and average receipts not over 14 and 15 . Will send you açcount of sales and check when sold. We look for a better condition of affairs soon.

Yours respectfully,

"E."

Philadelphia, June 25th, $18 \& 9$.

DEAR SIR :

We enclose you account of sales of the tub of butter received May 23rd, and check to balance. We regret that we can not return you a more satisfactory account of this sample tub, but our market has been in a very unsatisfactory condition for some weeks, with receipts very heavy and no butters except those showing fancy quality and No. 1 keeping quality have brought full prices. This quality your butter lacks. In fact, we have never had any from West Virginia that would fill requirements.

We shall always be pleased to receive your shipments, and, as a ruleour account sales and remittances are very prompt. "E."

\section{Dear Sir :}

Wheeling, IV. VA., May 23, 1889.

Please find, enclosed, check in payment of butter received from you. We disposed of this lot of butter, but have come to the conclusion, that we can not handle any more of it at present, so please do not send us any more of it unless we order. Country butter is so cheap that creamery butter has very small sale.

Regretting that we cannot use your product, we remain, Yours truly, "C. \& S."

DEAR SIR :

Baltumore, Md., May 22, 1889.

Please find, enclosed, statement of sales. Do not ship us any more butter. We are full just now. "P. \& S." 
We are fully aware that any one in looking over these letters would receive the impression that we were not making a good quality of butter, and that is evidently the impression that the commission merchants intended to make. 'These letters are quoted to show the difficulties with which a new creamery may expect to contend.

The creamery busines: is like any other business, in that those conducting it must establish for it a good name. When a creamery begins business, its managers must expect. to be met by this difficulty. The commission merchant has no interest in the creamery further than he can make it a source of profit to himself, either directly or indirectly, and the creamery dealing with him may expect a regular series of complaints similar to those above given. The truth of the matter is- we were shipping those merchants, as pure and excellent butter as can be made from the average milk delivered at a creamery, and we have every reason to believe that it reached them in good condition. It was a new enterprise, however, and we were naturally supposed to be quite sensitive to such criticisms. This, of course, would give ground for selling at less than the price of "fancy creamery." I doubt whether any creamery without an iron-bound contract for a regular delivery of so much butter per week the year around can get the average commission merchant to acknowledge that it is shipping to him a fancy product. It is human nature to buy as cheap and sell as high as possible, and it is wonderful how this phase of it develops when the creamery is located several hundred miles away from the city in which the butter is sold.

The privacy of business transactions prevents us from quoting from letters commending the butter, and for that reason alone we withhold them. They are, however, on file at our office and can he seen by parties interested. Suffice it to say that our butter is now daily upon the tables of the highest officers in the country, and in private cars and used by the families of railroad magnates and some of the most distinguished men of our nation.

\section{DIFFICULTIES TO BE OVERCOME.}

We found it impossible at first to enter into contracts with any of the hotels, or railroad eating houses or commission merchants to handle our product. We entered the field with the reputation of the butter of the State as bad as it could be; with a market to develop, and with all of the diffculties connected with handling and shipping butter to overcome. The confidence of the farmers was to be gained; the doubts in the minds of the Board of Regents were to be removed; the imperfections incident to the organization of the enterprise were to be overcome, and with it all insufficient facilities for storing and packing the butter, to hold it for a favorable market. Our local market was crushed by hundreds of pounds 
of country butter being delivered in the city which, run the price of country butter down to six cents per pound, and a drug upon the market at that.

At this stage in the enterprice, we made an effort to secure a market for cream in the ice cream saloons. We tried it in Wheeling and in a number of the railroad towns without success. We made an effort to secure a portion of the cream and milk trade at at Deer Park, but without success. At last an ice cream dealer in this city was induced to try our product, and it was soon found that no better ice cream could be made in the State than he was producing from our cream. This soon gave us an outlet for a portion of our product; and relieved the pressure upon our butter market. The farmers by their own bad management completely crushed the local market so that in a short time the butter market in the town was almost free from country butter, which ceased to come on account of the low price, and our local trade returned to us. A few parties of prominence were induced to try the butter and use it, and it has gradually worked its way until within six months from the time of starting, we find ourselves entirely unable to meet the demand for the product. Its character in the market is established, and we could really sell 1000 pounds per week, if the milk could be secured. Our struggle is now with the farmers to induce them to keep up the supply of milk to hold the trade developed.

\section{DIFFICULTIES WITH THE FARMER's.}

In the past they have had their cows come in in May or June when the maket is glutted with the country product, and when it is almost impossible to find a first class maket for large quantities of butter no matter how excellent it may be, instead of having the cows fresh in October or November when the butter products will be thrown upon the market at the time when butter is scarcest and commands the highest price, and also, when it will be possible for them to keep their cows longer in milk than by the present system.

The task before us has presented itself as follows:

1st. To build up the reputation of and create a market for West Virginia Creamery butter.

2 nd. To overcome the difficulties incident to handling and marketing the butter, and get the railrcad and express companies to furnish us proper facilities and rates for its transportation.

3rd. To educate the farmers to the idea that there is money in the business, and that it will pay them to engage in it.

4 th. To overcome the difficulties incident to all commercial enterprises of this character, with which every business man is familiar.

5th. To demonstrate to the farmers that it is possible to conduct a creamery through the winter in this climate as well as through summer. We are not certain yet whether we shall be able to carry out this demonstration, but our patrons insist 
now that they will stand by us and see us through, and endeavor to hold the market through the winter. So far as we are aware, each one patronizing the creamery is entirely satisfied with the result of his experience, and we believe that the darkest days of the industry in West Virginia are passed. When we began work in this State a year and a half ago, there was but one creamery in the State; now there are six, with prospects of several more.starting in the spring.

6 th. To advance our knowledge of the chemistry of milk and butter, and to improve upon the methods of handling both.

We believe that substantial progress has been made, and that the improvements proposed will be of no small value to the farmers of this State as well as to the country at large. 
iㅔㅅㅏ 